\title{
Editorial
}

\section{Perspectivas futuras da genética psiquiátrica}

O campo da genética psiquiátrica apresenta uma série de desafios particulares, uma vez que as mesmas doenças mentais se apresentam como quadros clínicos (fenótipos) complexos, para os quais existem, por um lado, várias explicações etiológicas. A partir da perspectiva genética, temos, em primeiro lugar, o fenótipo explicado por completo na etiologia de índole genética (genótipo), e, em segundo lugar, a etiologia que responde a outros fatores não genéticos (fenocópias). Além disso, encontramos, dentro dos tipos genéticos, a chamada heterogeneidade genética, em que vamos encontrar diferentes genes que causam a mesma patologia.

Nesse sentido, um dos grandes desafios desse campo é tentar aprimorar a busca de novas definições dos fenótipos psiquiátricos que nos permitam identificar com maior precisão a localização de seus genes.

Com esse objetivo, procurou-se diferenciar, seja clinicamente ou por meio de marcadores biológicos particulares, as variedades genéticas das fenocópias, assim como encontrar as condições que permitem distinguir as próprias formas genéticas e a relação existente entre o fenótipo clínico e o genótipo específico.

Quanto à perspectiva clínica, alguns dos métodos propostos consistem em caracterizar as patologias mentais de acordo com características como: instalação da doença, antecedentes hereditários, severidade, evolução clínica, preponderância de sintomas característicos (por exemplo, sintomas positivos e negativos nas psicoses), co-morbidade, gênero e resposta ao tratamento.

Por outro lado, quanto aos marcadores biológicos propostos, tem-se tentado definir os fenótipos clínicos, de acordo com as áreas de pesquisa que permitiram um melhor conhecimento da etiopatogenia das doenças mentais. Como exemplos, temos os seguintes:

1. Imagens cerebrais particulares, tanto do tipo estrutural (CAT, RMN) como dinâmicas (PET, SPECT, RMN-funcional);

2. A execução e avaliação do funcionamento neuropsicológico e variáveis eletrofisiológicas, como potenciais evocados e EEG (hoje muito importantes em pesquisa de patologia mental e de processos cognitivos normais);

3. O estudo de marcadores biológicos mais tradicionais, como têm sido os bioquímicos, psicofarmacológicos e endocrinológicos. Por intermédio deles tentaram-se desafios do funcionamento específico para os diferentes sistemas de neurotransmissão. Dessa maneira, espera-se ter uma maior informação sobre um ponto mais preciso onde se poderia encontrar a alteração genética particular das cascatas metabólicas da neurotransmissão do SNC;

4. Relacionado ao item anterior, há um interesse crescente em conhecer de que maneira as variações polimórficas moleculares dos pontos de ação para os diferentes psicofármacos podem ter um impacto nos mecanismos de farmacocinética e farmacodinâmica. Isso equivale a determinar ou prognosticar a resposta terapêutica e os efeitos colaterais;

5. Duas áreas de pesquisa básica, que mais recentemente ganharam importância: o estudo dos mecanismos moleculares imunológicos e a pesquisa dos processos de expressão dos genes durante o neurodesenvolvimento.

Finalmente, o uso de procedimentos rigorosos da genética molecular - como a triagem para todo o genoma por meio de marcadores distribuídos cada vez mais intensamente - e modelos animais de inativação para certos genes (knockouts) que pudessem ser relevantes ou, como também têm sido chamados, "genes candidatos", continuamente dão novas informações dos possíveis loci envolvidos em patologias psiquiátricas. Tais metodologias moleculares relacionadas aos avanços na metodologia epidemiológica e estatística, aplicadas ao estudo dos efeitos genéticos nas patologias mentais, se apóiam nos estudos tradicionais de associação de genes (linkage), análise de segregação e o estudo do fenômeno de antecipação genética. $\mathrm{O}$ estudo de genes associados à doença mental, seja por meio de trios ou do risco relativo por haplótipo (HRR), representam também uma área que dá lugar a constante informação, embora exista certa controvérsia quanto aos seus resultados.

Como podemos apreciar, o grande número de métodos de pesquisa que estão sendo empregados faz da genética psiquiátrica uma das áreas da ciência médica mais diversificada e com grandes possibilidades de dar uma nova perspectiva ao entendimento da doença mental.

Humberto Nicolini Instituto Mexicano de Psiquiatría 